\title{
Multiple sclerosis and myelin basic protein: insights into protein disorder and disease
}

\author{
Vebjørn Martinsen $^{1} \cdot$ Petri Kursula ${ }^{1,2}$ (1)
}

Received: 11 June 2021 / Accepted: 24 November 2021 / Published online: 10 December 2021

(c) The Author(s) 2021

\begin{abstract}
Myelin basic protein (MBP) is an abundant protein in central nervous system (CNS) myelin. MBP has long been studied as a factor in the pathogenesis of the autoimmune neurodegenerative disease multiple sclerosis (MS). MS is characterized by CNS inflammation, demyelination, and axonal loss. One of the main theories on the pathogenesis of MS suggests that exposure to foreign antigens causes the activation of cross-reactive $T$ cells in genetically susceptible individuals, with MBP being a possible autoantigen. While a direct role for MBP as a primary antigen in human MS is unclear, it is clear that MBP and its functions in myelin formation and long-term maintenance are linked to MS. This review looks at some key molecular characteristics of MBP and its relevance to MS, as well as the mechanisms of possible molecular mimicry between MBP and some viral antigens. We also discuss the use of serum anti-myelin antibodies as biomarkers for disease. MBP is a prime example of an apparently simple, but in fact biochemically and structurally complex molecule, which is closely linked to both normal nervous system development and neurodegenerative disease.
\end{abstract}

Keywords Myelin $\cdot$ Multiple sclerosis $\cdot$ Myelin basic protein $\cdot$ Disorder $\cdot$ Disease

\section{Introduction}

The word myelin stems from the Greek word for marrow (myelos), devised by the German pathologist Rudolf Ludwig Carl Virchow (1821-1902) in 1854 (Virchow 1854; Boullerne 2016), while the myelin structure had already been observed in the early eighteenth century (Van Leeuwenhoek 1719). The myelin sheath is a multilayered proteolipid membrane, which is involved in neural insulation and saltatory conduction of nerve impulses. It is, therefore, important in the function of both the central (CNS) and peripheral nervous system (PNS). Destruction of the myelin sheath causes neurodegeneration and conduction failure, as observed in demyelinating diseases, such as multiple sclerosis (MS)

Handling Editor: E. I. Closs.

Petri Kursula

petri.kursula@uib.no

1 Department of Biomedicine, University of Bergen, Jonas Lies vei 91, 5020 Bergen, Norway

2 Biocenter Oulu and Faculty of Biochemistry and Molecular Medicine, University of Oulu, Aapistie 7, 90220 Oulu, Finland and acute disseminated encephalomyelitis (ADEM) in the CNS, and Guillain-Barré syndrome (GBS) and Charcot-Marie-Tooth disease (CMT) in the PNS. CMT is an inherited peripheral neuropathy, linked to mutations in dozens of different genes (Stavrou et al. 2021). The most common of these myelin disorders, and the focus of this short review, is MS.

MS is a multifactorial, autoimmune, demyelinating, neurodegenerative disease with an unknown pathogenesis (McGinley et al. 2021). It is characterized by CNS inflammation, demyelination, and axonal loss, as well as attempts at re-myelination by oligodendrocytes. One of the leading theories is that MS is caused by an aberrant immune response in genetically susceptible individuals (Fujinami and Oldstone 1985). MS is, thus, generally considered an autoimmune disease. Some research on the pathogenesis of MS has focused on the possible link between MS and an abundant protein found in CNS myelin, the myelin basic protein (MBP).

MBP is the second-most abundant protein in myelin, constituting 30\% of the total CNS myelin protein. It was first isolated in the early 1960s (Einstein et al. 1962), being the most widely studied myelin protein in relation to MS. MBP, earlier called basic A1 protein, was first sequenced from 
bovine spinal cord and human myelin 50 years ago (Eylar 1970; Carnegie 1971; Eylar et al. 1971). It is an intrinsically disordered protein (IDP) (Harauz et al. 2009; Majava et al. 2010), lacking a well-defined globular structure, and it can change its conformation depending on its environment and interactions. Most importantly, upon binding to lipid bilayer surfaces, MBP folds into a-helical structures and attaches tightly to the membrane (Harauz et al. 2009; Muruganandam et al. 2013; Raasakka et al. 2017). Upon interacting with its partner proteins, MBP likely forms short structured segments. The flexibility and adaptability of IDPs have been of growing interest in the field of structural biology, to a large extent due to an overall increasing focus on protein disorder and biological liquid-liquid phase separation. Being an IDP suggests that MBP could be a multifunctional protein (Tompa et al. 2005). It has been shown that MBP binds to and interacts with several other proteins, such as calmodulin and cytoskeletal proteins (Baryłko and Dobrowolski 1984; Chan et al. 1990; Majava et al. 2008; Harauz and Libich 2009; Smith et al. 2012), and it has been suggested to play a role in signaling pathways (Boggs 2006; Boggs et al. 2011; Vassall et al. 2015).

Extensive research has been done on both MBP and the possible role it plays as a source for autoantigenic epitopes in MS. It is largely undisputed that there are changes in the isoform composition and structure of MBP, as well as in compact myelin, during the pathogenesis of MS (Wood et al. 1996; Beniac et al. 1999; Boggs et al. 1999). The mechanisms of such changes are not clear at the molecular level. It is possible that an abnormal isoform composition of MBP leads to weakened membrane interactions and loosening of the rigid myelin structure. This may further lead to the observed anti-MBP immunoactivity as well as the presence of MBP in the cerebrospinal fluid (CSF). Whether the latter can be used as a biomarker of disease, is still under debate.

This short review will discuss some of the important aspects of MBP with regard to MS. It will take a brief look at the use of animal models for demyelinating disease and related challenges. Lastly, it will look at one of the leading theories today; the possible relationship between certain foreign antigens and the development of MS. The usefulness of MBP as a biomarker for MS is additionally discussed.

\section{Diagnostic criteria for multiple sclerosis}

Clinically definite multiple sclerosis was defined by Poser et al. in "Diagnosis of Multiple Sclerosis: guidelines for research protocols" in 1983 as: two attacks with clinical evidence of separate lesions, or two attacks: with clinical evidence of one lesion and para-clinical evidence of another. The two attacks must be separated in space (different parts of CNS) and time (at least one month). The attack must last for at least $24 \mathrm{~h}$ (Poser et al. 1983).

Diagnosis of multiple sclerosis as defined by McDonald criteria was established in 2001 by a team of researchers as a means of standardizing the diagnosis of multiple sclerosis. These criteria, like those for clinically definite multiple sclerosis, require evidence of damage disseminated in space and time. The McDonald criteria also incorporate the use of magnetic resonance imaging to establish the MS diagnosis (Gobbin et al. 2019).

\section{The structure of myelin}

The overall structure of myelin is similar in the PNS and CNS, despite the differences in molecular composition and the fact that CNS myelin is made by oligodendrocytes and PNS myelin by Schwann cells. Myelin is a repetitive multilayer of tightly packed lipid bilayers, which are held together by specific myelin proteins, one of which is MBP. Myelin proteins are among the most long-lived proteins in the body (Toyama et al. 2013; Fornasiero et al. 2018), which reflects the importance of the stability of this macroscopic supramolecular structure to the normal functioning of the nervous system.

During myelination, the myelinating cell wraps its plasma membrane around a selected axon (Fig. 1A) in a dynamic process, which involves growth of the inner tongue of the immature myelin membrane (Snaidero et al. 2014). Upon MBP expression by the oligodendrocyte (Colman et al. 1982), compaction occurs, resulting in the formation of the MBP-rich major dense line as well as the intra-period line at the extracellular apposition. The resulting compact CNS myelin has a very low solvent content, being essentially formed of lipid and protein, while cytoplasmic nanochannels allow for transport of metabolites and signaling (Snaidero et al. 2017).

In MS, inflammation of the CNS targets an immune attack toward the myelin sheath (Fig. 1B). This results in the deterioration of the myelin structure, eventually leading to decreased nerve conduction velocity and neurological symptoms. Re-myelination of the sites of insult can occur via different mechanisms (Neumann et al. 2019; Franklin et al. 2020); this is an intense topic for current research in MS therapy, with a strong focus on stem cell approaches (Genc et al. 2019; Esmaeilizade et al. 2021).

\section{MBP size isoforms are products of alternative splicing}

MBP exists as several size and charge isoforms, some of which have a possible link to the pathogenesis of MS (Vassall et al. 2015). The MBP size isoforms result from 

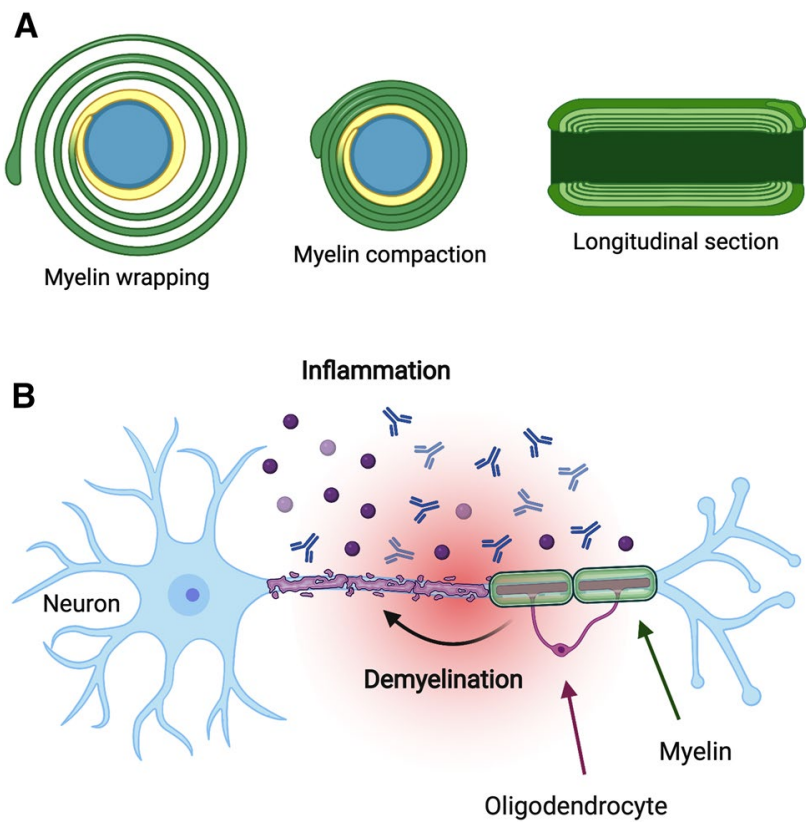

Fig. 1 Myelin formation and degradation. A During myelination, the myelinating cell wraps its plasma membrane around the axon dozens of times (left). The expression of MBP then induces compaction of this multilayer (middle), into a tightly packed proteolipid devoid of aqueous solvent. The longitudinal section (right) shows a single myelin sheath, bounded by two nodes of Ranvier. B During inflammation in an MS plaque, demyelination occurs, leading to neuronal damage and slowing down of nerve impulses, as saltatory conduction is impaired. The figure was prepared using BioRender

alternative splicing of an mRNA transcript (Boggs 2006). The charge isoforms, the focus of the next chapter, are generated by post-translational modifications of a particular MBP size isoform; these modifications decrease the positive charge of MBP and affect its function.

Classic MBP is a product of the Golli (genes of oligodendrocyte lineage) gene complex. Golli gives rise to both the classical MBP and the Golli MBP. Golli MBP proteins are found in the hemopoietic system (Grima et al. 1992), while canonical MBP is thought to only exist in myelin. In humans, the Golli complex has 10 exons, 7 of which give rise to MBP (Givogri et al. 2001). Human MBP consists of 4 different size isoforms of 17.2, 18.5, 20.2, and $21.5 \mathrm{kDa}$. The $18.5-\mathrm{kDa}$ isoform is the most abundant type in adult human myelin, and by far the most extensively studied. All four isoforms contain domains encoded by exons 1, 3, 4, 6, and 7 (Voskuhl et al. 1993). Domains encoded by exon 2 can only be found in the two largest size isoforms (i.e., 20.2- and 21.5-kDa size isoforms), making these exon $2+$ (positive) and the 17.2- and 18.5-kDa size isoforms exon 2- (negative) forms of MBP (Boggs 2006).

The two different subgroups of MBP (i.e., exon $2+$ and exon 2-) have been found to dominate in different stages of oligodendrocyte and subsequent myelin development, in both humans and mice (Barbarese et al. 1978). The exon $2+$ size isoforms of MBP predominate in early stages of myelination, while exon 2- MBP is characteristic of later stages of myelination and adult mature myelin. The same applies for immature and mature oligodendrocytes, respectively. In humans, the exon $2+\mathrm{MBP}$ is seen in fetal development and during re-myelination (Gogate et al. 1994). The functional differences between the different size isoforms at the molecular level are currently poorly known.

The discoveries mentioned above gave rise to the hypothesis that exon $2+$ MBP might express immunodominant epitopes that are not present in the adult exon 2- MBP. In 1993, Voskuhl et al. published a study on the possible T lymphocyte recognition of an epitope on exon $2+$ MBP. At the time, such epitopes were not known. Since there is enhanced expression of exon 2+MBP transcripts in re-myelination after myelin loss, autoimmunity against an immunodominant epitope on this protein would be of interest in the pathology of MS. Voskuhl et al. found that there, indeed, were epitopes on the exon $2+$ isoforms recognized by human $\mathrm{T}$ cells, thus providing a possible mechanism for progression of MS. In this model, regenerating myelin and immature oligodendrocytes are targets of a T cell-mediated immune response (Voskuhl et al. 1993; Gogate et al. 1994).

\section{Post-translational modification gives rise to charge isoforms of $18.5 \mathrm{kDa}$ MBP}

18.5-kDa MBP exists as 8 different charge isoforms. These are termed $\mathrm{C} 1-\mathrm{C} 8$ and are products of various post-translational modifications, decreasing the net charge of MBP. C1 is the least modified charge isoform of $18.5 \mathrm{kDa} \mathrm{MBP}$, and thus, the charge isoform with the highest positive charge. C2-C6 are modified by, among others, phosphorylation, deamidation, and deimination. $\mathrm{C} 8$ is modified by peptidyl arginine deiminase that converts arginine to citrulline (citrullination). This is done for 6-11 arginine residues, with a loss of net positive charge by one for every arginine-tocitrulline conversion (Wood and Moscarello 1989). Like observed for the exon 2+ and exon 2- MBP (see above), the specific charge isoforms seem to dominate at different stages of myelin development and provide different levels of myelin stability. $\mathrm{C} 1, \mathrm{C} 2$, and $\mathrm{C} 3$ are considered to be a part of a stable myelin sheath, while $\mathrm{C} 8$ is suggested to have a role in development, with a peak in childhood and subsequent decrease in adults. Hence, the $\mathrm{C} 8$ charge isoform might be of importance for the formation of myelin rather than its stability (Wood and Moscarello 1989). The focus of this chapter will be on reported changes in proportion of different charge isomers and arginine deimination in MS brain.

The importance of the various charge isoforms of MBP has been studied for decades, and the developmental 
properties of the $\mathrm{C} 8$ isoform have been of interest in research on MS, especially with regard to the association of $\mathrm{C} 8$ with destabilized compact myelin. It has been found, when comparing the various charge isoforms of $18.5 \mathrm{kDa} \mathrm{MBP}$ in normal human white matter and white matter from an MS patient brain, that there are several differences. A study published in 2003 found that, while the proportion of $\mathrm{C} 2$, $\mathrm{C} 3, \mathrm{C} 4$, and C5 did not differ significantly between the two groups, $\mathrm{C} 1$ was decreased in MS white matter, while C8 was increased in MS white matter compared to the normal brain (Kim et al. 2003). This could be explained as an indication of attempted re-myelination.

Furthermore, the same study (Kim et al. 2003) found more deiminated arginine residues in MS white matter than in normal white matter, specifically showing that $\mathrm{C} 4$ and C5 were deiminated to a greater extent in MS tissue than normal. The study also showed a difference in deimination of C8 between two MS white matter samples. One sample from a mild case of MS showed deimination on several residues, but to a relatively lesser extent. Another sample was from a younger patient with a more aggressive disease and showed extensive deimination of all arginine residues tested. Therefore, a correlation between extent of deimination and severity of disease was postulated (Kim et al. 2003).

At the molecular level, there are many consequences of an increased deimination of arginine residues in MBP. As explained above, MBP loses one net positive charge for each deiminated arginine residue. This results in a less cationic protein, decreased ability to interact with negatively charged lipids, and subsequent decrease in stability and compaction of myelin, further resulting in possible myelin loss (Mastronardi and Moscarello 2005). Second, as reported by Cao et al. in 1999, the degradation of citrullinated MBP by cathepsin D (a myelin-associated protease) was much more rapid than that of MBP $\mathrm{C} 1$. It was hypothesized that citrulline might have a stabilizing effect on encephalitogenic peptides in MS (Cao et al. 1999). Furthermore, it was observed that the HLA haplotypes associated with greatest genetic risk for MS (HLA-DRB1*15:01 and HLA-DRB5*01:01) preferentially presented peptides that were citrullinated at particular HLA-binding sites (Nguyen and James 2016).

\section{MBP is an intrinsically disordered protein with propensity to fold locally}

Biochemically, MBP has unique properties. It carries a high positive charge, having an isoelectric point of $\sim 11$. Since the first structural investigations $>50$ years ago (Chao and Einstein 1970), a large number of studies have characterized MBP as an IDP (Krigbaum and Hsu 1975; Harauz et al. 2009; Majava et al. 2010; Wang et al. 2011; Raasakka et al. 2017), indicating that MBP is highly flexible and possibly able to interact with multiple binding partners. Indeed, while MBP has been well characterized as a membrane-binding protein (Harauz and Libich 2009; Wang et al. 2011; Vassall et al. 2015; Raasakka et al. 2017), it additionally has a number of protein-protein interaction partners (Baryłko and Dobrowolski 1984; Chan et al. 1990; Roth et al. 1993; Libich and Harauz 2002; Majava et al. 2010; Boggs et al. 2011; Smith et al. 2012). The interplay of these different interactions is important for the correct formation of myelin (Snaidero et al. 2017).

As the structure of MBP is flexible, without a compact 3D fold, an analysis of MBP sequence conservation can shed light on functionally relevant segments. Selected MBP sequences have been aligned in Fig. 2A, showing strong conservation of certain segments. On the basis of earlier literature, these conserved sites correspond to those binding to the lipid bilayer, or to other proteins. To complement these analyses, bioinformatics-based tools can be used to predict MBP properties (Fig. 2B). The DynaMine prediction (Cilia et al. 2014) suggests 3 regions with a rather rigid structure, possibly being context-dependent. These regions correspond to the known membrane- and/ or calmodulin-binding sites. The PONDR prediction of disorder (Obradovic et al. 2003; Xue et al. 2010; Cilia et al. 2014) is in line with the above analysis, showing disordered segments between the membrane-binding sites. The membrane-binding sites are known to fold into helices upon membrane embedment (Harauz et al. 2009; Muruganandam et al. 2013; Raasakka et al. 2017).

Characteristic to myelin compaction in the CNS is the transport of MBP mRNA to oligodendrocytic processes, which are about to compact (Ainger et al. 1993, 1997; Barbarese et al. 1995; Carson et al. 1997). MBP acts as a trigger to glue apposing membranes together (Fig. 1A). Its interaction with lipid surfaces is essentially irreversible, and it forms a brush-like phase onto the membrane surface, which is then attractive toward a second lipid bilayer (Raasakka et al. 2017). Liquid-liquid phase separation appears to play a role in this process (Aggarwal et al. 2013), which eventually produces the major dense line, corresponding to the fusion between two apposing cytoplasmic leaflets of the myelin membrane. MBP is crucial for the formation of the major dense line in the CNS myelin.

Interestingly, the disease mechanisms of amyotrophic lateral sclerosis (ALS) involve mRNA transport and liquid-liquid phase separation, which both are attributes related to MBP in oligodendrocytes. Although ALS is a neuronal disease, oligodendrocytic pathology has been described and linked to a decrease in MBP (Nonneman et al. 2014; Zhou et al. 2017; Wang et al. 2018). The deficiency of oligodendrocytic mRNA transport may cause collateral damage to myelinating cells in addition to neurons per se. 
A
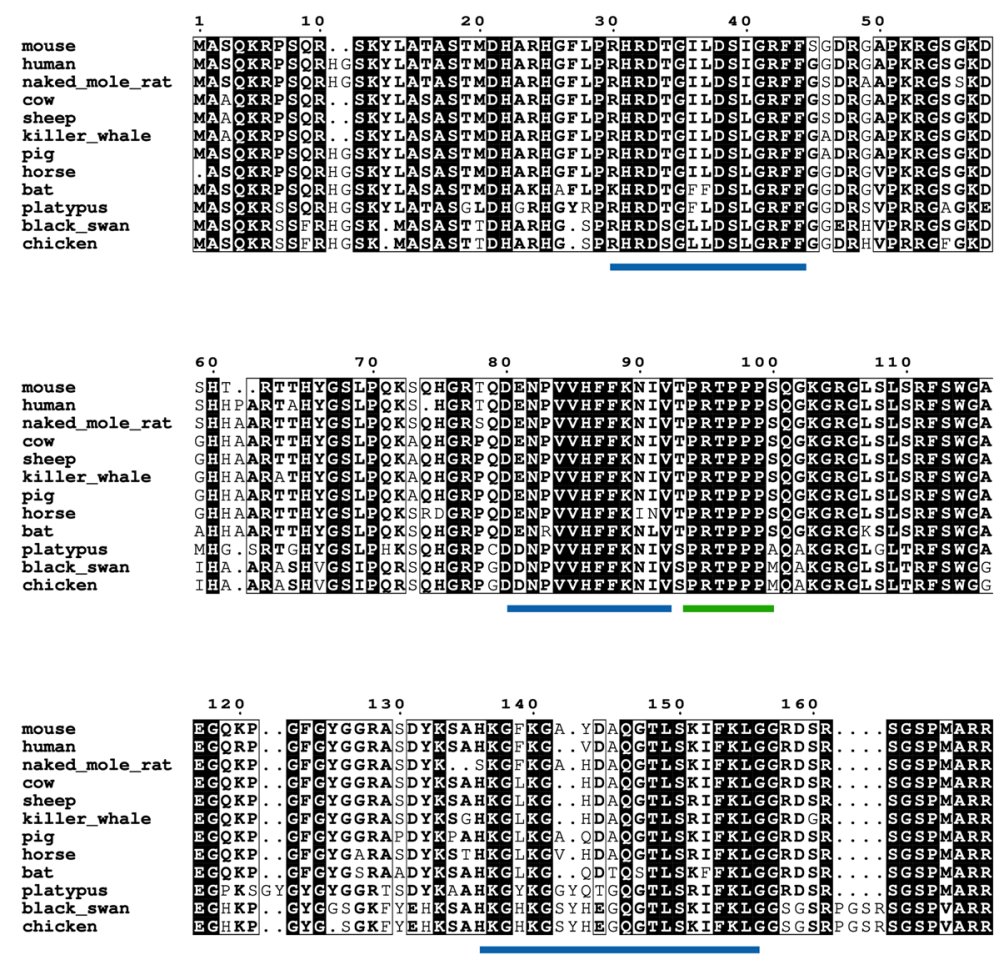

B

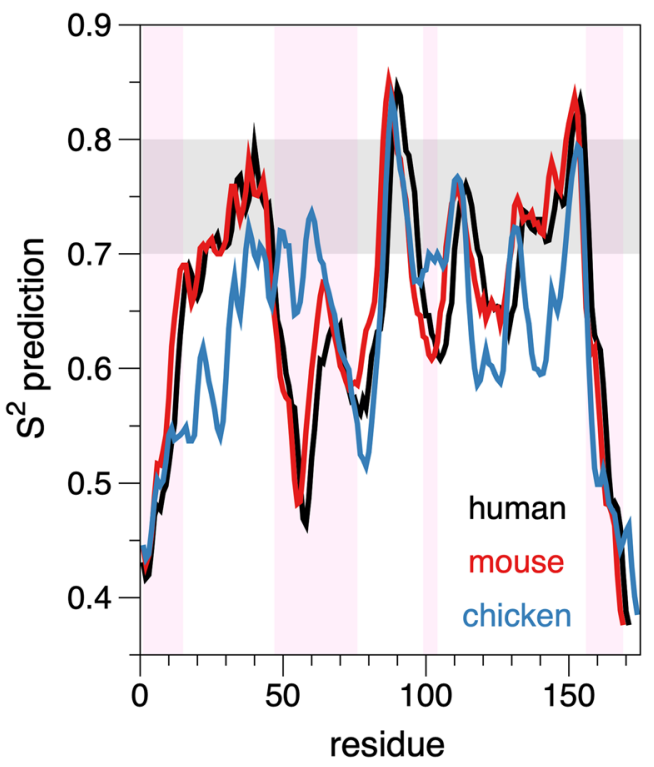

Fig. 2 Conservation and intrinsic disorder in MBP. A Alignment of MBP sequences from selected tetrapods. Clearly defined conserved segments are detected, which correspond to regions predicted to fold into helices upon molecular interactions with, e.g., lipid membranes or other proteins. The segments marked in blue interact with membranes and/or calmodulin, while the SH3 domain-binding site (Polverini et al. 2008) is indicated in green. The figure was prepared using ESPript (Gouet et al. 1999). B. Bioinformatics analysis

\section{Animal models for the study of MBP and demyelinating diseases}

With regard to MBP, a mouse model, the shiverer (Readhead and Hood 1990), is of historical relevance. First described in the 1970s, shiverer mice have abnormal CNS myelin, while PNS myelin appears normal (Bird et al. 1978; Dupouey et al. 1979; Privat et al. 1979). At the molecular level, shiverer mice were observed to be deficient in MBP (Dupouey et al. 1979). Hence, the shiverer mouse is a spontaneous knockout line for MBP, originating from a time, when current technologies for generating mutant mice were not yet available. The shiverer mouse is still a widely used animal model for studying myelination and MBP-related processes therein.

The most widely used experimental animal model for MS is experimental autoimmune encephalomyelitis (EAE). EAE is an immune and neuropathological condition, consisting of CNS inflammation, demyelination, axonal loss, and gliosis, which all are key components of MS pathology (Constantinescu et al. 2011). EAE is induced by stimulating a T-cell-mediated immune response against myelin antigens of MBP sequences indicates conserved order/disorder between species, and the molecular interaction sites have a propensity to fold into rigid structures. Plotted is the DynaMine (Cilia et al. 2014) flexibility prediction for human, mouse, and chicken $18.5 \mathrm{kDa}$ MBP. Values above 0.8 predict rigid structure, $0.7-0.8$ suggests context-dependent folding, and below 0.7 , the protein is predicted to be disordered. The shading in pink highlights mouse MBP regions predicted to be disordered by PONDR (Xue et al. 2010)

(Stromnes and Goverman 2006a). There are two forms of EAE, active and adoptive-transfer (AT), caused by different methods of induction. Active EAE is induced by immunizing with an array of tissue and myelin peptides. Among these are MBP and peptides derived from it. AT EAE is induced by immunization of a model animal with myelin-specific $\mathrm{CD} 4^{+} \mathrm{T}$ cells from a donor animal (Stromnes and Goverman 2006b).

EAE is considered a versatile model of neuro-inflammation and demyelination, being used as a model for studying protective mechanisms. A key factor in this versatility is that different induction methods, animal models, and response to pharmacological intervention cause a variety of outcomes. Although this versatility comes with the possibility to tailor the model to a specific study, such as modeling different forms of MS, it also causes problems for the translation from an animal model of MS to the actual disease in humans (Constantinescu et al. 2011).

Several of the disease-modifying therapies (DMT) for MS have been, at least partially, related to studies on EAE. A DMT termed GA (glatiramer acetate), trade name Copaxone, 
is one of these, with a tight link to EAE. GA is a copolymer consisting of a specific ratio of the amino acids tyrosine, glutamine, alanine, and lysine, and it physico-chemically resembles MBP (Stapulionis et al. 2008; Jalilian et al. 2012). GA was first developed by Teitelbaum et al. in 1971 as a potential encephalitogen, but it instead turned out to be an effective blocker of EAE (Teitelbaum et al. 1971).

Altered peptide ligands (APL) of MBP have been studied as treatments for EAE, the concept being that substitution of one or more amino acids of the APL would interfere with MHC or T cell receptor-binding properties and cause tolerance to the native peptide through various mechanisms (Constantinescu et al. 2011). An in vivo study on this hypothesis showed tolerance in a murine model immunized with a particular MBP-specific T cell clone (Brocke et al. 1996). This same theory was tested in MS patients, but the trial was discontinued, because $9 \%$ of patients developed hypersensitivity reactions. Another phase II clinical trial found that MBP APL could lead to exacerbation of MS. This led to two conclusions: one being the confirmation of a link between autoimmunity toward MBP and MS. The second conclusion was that EAE as a model for MS is highly relevant, but great care should be taken to understand underlying mechanisms, when extrapolating from EAE to MS and considering specific immunotherapies (Bielekova et al. 2000; Constantinescu et al. 2011).

\section{Anti-myelin antibodies as predictors for the development of multiple sclerosis after a first demyelinating event}

Anti-myelin antibodies (anti-MOG and anti-MBP) have long been targets of interest in MS research, and some foci of interest have been the relevance of anti-MBP antibodies as a possible cause of MS, as well as anti-myelin antibodies as markers for severity of disease or as markers for risk of progression. Many of the answers to these research questions remain uncertain, and conflicting results exist. Furthermore, serum IgG antibodies against MBP were shown to potentially distinguish ADEM from MS (Van Haren et al. 2013). In this chapter, we will look closer at the possible clinical use of testing for serum anti-myelin antibody status in patients, who experience a first demyelinating event associated with MS.

After a first demyelinating event, there is an elevated risk of developing MS, but the outcome for the individual is uncertain. This demyelinating event is called a clinically isolated syndrome (CIS) (Miller et al. 2012), and most MS patients present with such an event (Villar et al. 2011). CIS is defined as a single demyelinating event affecting the central nervous system; the episode must last at least $24 \mathrm{~h}$, and there must not be any association to other organic disease (fever, infections, metabolic disorders, etc.). The increased long-term risk of the patient for developing MS depends on the detection of additional brain lesions on magnetic resonance imaging (MRI) scans. When CIS is accompanied by such findings, and the lesions are similar to those found in MS, the patient has a $60-80 \%$ risk of a second demyelinating event and an MS diagnosis. For patients with a normal MRI scan, except for the symptomatic lesion, the risk for progression is $\sim 20 \%$ (Miller et al. 2012).

Kuhle et al. published in 2007 an article on establishing anti-MOG and anti-MBP antibody status in patients with CIS and its predictive value for progression to clinically definite MS or a diagnosis of MS as defined by the McDonald criteria (Kuhle et al. 2007b). In this study, anti-myelin antibody status was established for 462 patients, whereby $52 \%$ and $36 \%$ tested positive for anti-myelin $\operatorname{IgM}$ and $\operatorname{IgG}$ antibodies, respectively. The rest of the patients tested negative for both anti-MOG and anti-MBP, both IgM and IgG. The study was done on patients recruited to the BENEFIT trial (Betaferon in Newly Emerging Multiple sclerosis for Initial Treatment), a trial that studied the effect of interferon beta- $1 \mathrm{~b}$ on patients with CIS.

Earlier results suggested an association between serum anti-myelin antibody status and prognosis for patients after a first demyelinating event, and that analysis of anti-MOG and anti-MBP antibody status could be used to estimate individual risk for progression of disease (Berger et al. 2003). Kuhle et al. however, found no "increase in the risk of clinically definite multiple sclerosis or of multiple sclerosis according to the McDonald criteria among patients who were positive for anti-MOG antibodies, anti-MBP antibodies, or both" (Kuhle et al. 2007b). This was the conclusion for not just the total study population, but for all subgroups analyzed. Accordingly, while anti-MOG and anti-MBP antibodies are correlated to inflammatory signs in MS patients, their prognostic value for predicting MS progression is questionable (Kuhle et al. 2007a).

The above findings are supported by a cohort study conducted by Pelayo et al. (Pelayo et al. 2007). In addition to investigating the association between serum anti-myelin antibody status and rate of progression to clinically definite multiple sclerosis, the group looked at the association regarding time to conversion for patients, who converted to clinically definite MS during the follow-up period (mean of $46.7 \pm 21.2$ months). The conclusion, like that of Kuhle et al. (2007b), was that there were no significant differences between anti-myelin antibody-positive patients and antimyelin antibody-negative patients in the rate of conversion. Likewise, for patients progressing to clinically definite MS during the follow-up period, no significant difference was found in the median time to conversion between the two groups (Pelayo et al. 2007). 
It would, thus, seem that the clinical relevance of establishing a patient's serum anti-myelin antibody status for the purpose of evaluating the individual risk for progression to clinically definite MS after a CIS is, at this time, limited and uncertain. Many other possible markers for risk of disease progression have been investigated with varying results. Among these are transcription factors, cell membrane receptors, and cytokines, particularly those involving immune cells.

One marker showing promising results in a study published in 2011 was $\mathrm{CD}^{+} \mathrm{B}$ cells (Villar et al. 2011). It is known that these cells are involved in certain types of autoimmune disease. The study found that an increase in the percentage of $\mathrm{CD}^{+} \mathrm{B}$ cells in blood was associated with a higher risk of progression from CIS to clinically definite MS. It was postulated that this marker, therefore, could be useful for improving the efficacy of the prognosis for individual patients, but that further investigation on a larger scale is required (Villar et al. 2011).

A biomarker for the risk of progression in patients with CIS would have great clinical value, both to initiate drug therapy and to combat the uncertainty of outcome for the individual patient. A marker found in serum would be preferred over a marker in the CSF, considering the risk of harvesting test samples. While putative biomarkers have been found in small-scale studies, more investigation is needed on this topic.

\section{Cross-reactivity caused by similarities between viral antigens and MBP epitopes}

Cross-reactivity to exogenous antigens and self-antigens, termed molecular mimicry, has been a proposed mechanism, causal and exacerbating, of many autoimmune diseases. This builds on the theory that exposure to a foreign antigen with a similar amino acid sequence or structure to host antigens can cause an autoimmune response. Examples of diseases, in which this is seen as a plausible cause, are heart damage after rheumatic fever with Streptococcus pyogenes infection and the association between Campylobacter jejuni and Guillan-Barré syndrome (Cusick et al. 2012), an autoimmune demyelinating condition of the PNS. This chapter will discuss molecular mimicry related to $\mathrm{MBP}$ as a putative mechanism in the pathogenesis of MS. It should be noted that many other theories on the pathogenesis of MS exist, being a complex chronic inflammatory disease, including autoimmune reaction against GDP-L-fucose synthase (Planas et al. 2018), as well as both environmental and genetic factors (Ghasemi et al. 2017). The various factors involved have recently been reviewed in detail elsewhere (Gasperoni et al. 2019).
The hypothesis of molecular mimicry related to microbial and viral pathogens in MS pathogenesis has long been popular, especially related to the Epstein-Barr virus (EBV), and some of the research conducted on the subject has focused on MBP itself as a possible target autoantigen. It has been proven that cross-reactions between EBV and MBP do exist, but there are also cross-reactions between MBP and other viruses. There is a strong correlation between MS and EBV, with EBV infection in adolescence and young adulthood being one of the best-known environmental risk factors in MS (Guan et al. 2019). Therefore, as stated by Füst in 2011, "a cross-reaction itself can hardly be responsible for the relationship between EBV and MS" (Füst 2011).

In a study that structurally aligned single-chain variable fragments $(\mathrm{scFv})$ from blood lymphocytes of MS patients selected toward MBP (Gabibov et al. 2011), high homology was found between the variable regions of CSF MS-associated antibodies and antibodies toward EBV latent membrane protein 1 (LMP1). One scFv clone showed natural crossreactivity, reacting with both MBP and LMP1 in vitro. The authors concluded that antibodies induced against LMP1 during EBV infection might act as an inflammatory trigger by reacting with MBP, thereby suggesting molecular mimicry as a direct mechanism in the pathogenesis of MS (Gabibov et al. 2011).

A more recent study looked at the humoral immune response toward EBV nuclear antigen-1 (EBNA-1) in MS patients (Jog et al. 2020). A qualitative difference was found between the anti-EBNA-1 antibody in MS patients and healthy controls, stemming from the recognition of unique epitopes in MS patients that were not recognized in the control group. The authors saw that anti-EBNA-1 found in MS patients had, unlike that from the controls, crossreacted with MBP. The antibody that cross-reacted was antiEBNA $_{411-426}$. When a murine model was immunized with EBNA $_{411-426}$ peptides, varying levels of the clinical symptoms of EAE were observed. This led to the conclusion that the cross-reactive sequence of EBNA-1 can cause an antiMBP response in mice (Jog et al. 2020).

\section{MBP itself as a biomarker of myelin damage}

In addition to anti-MBP antibodies, the MBP protein per se has been studied and used as a possible biomarker for brain tissue injury and neurodegenerative disease, both in serum and in the CSF (Barkhof et al. 1992; Katsavos and Anagnostouli 2013; Zavialova et al. 2017; Kim et al. 2018). Being an integral component of compact myelin, the detection of MBP in the CSF is a direct sign of myelin breakdown. In line with this, MBP and its fragments can be detected in the CSF of most MS patients during relapse (Lamers et al. 1998; Sellebjerg et al. 1998). However, it has been suggested that the added value of testing 
the CSF for MBP in MS diagnosis is low (Greene et al. 2012). In addition to MS, MBP has been detected in the CSF in a number of neurodegenerative conditions, including ADEM (Re and Giachetti 1999; Koshihara et al. 2014), encephalitis (Jacque et al. 1982), acute cerebral infarction (Strand et al. 1984), and neuro-Behcet's disease (Ohta et al. 1980). The presence of MBP in serum or the CSF is an indication of myelin damage in general, and testing for it may be applicable to diagnosis of different neurodegenerative disease states, including spinal cord demyelination (Ohta et al. 2002).

\section{Concluding remarks}

Multiple sclerosis is a devastating chronic disease with an unknown mechanism of pathogenesis at the molecular level. One of the leading theories currently is that exposure to foreign antigens, in combination with environmental and genetic factors, causes a cross-reactive $\mathrm{T}$ cell-mediated immune response in susceptible individuals. A possible autoantigen target for this cross-reactive immune response is MBP and peptides derived from it, leading to demyelination and onset of disease. Getting a clearer understanding of the causes of MS, as well as identifying reliable biomarkers, would have a large impact on the treatment and prevention of MS and, thus, of great relevance for individuals at high risk or already affected by MS. However, more research will, indeed, be needed to reach such a goal.

Author contributions Initial drafting of the manuscript: VM; final editing of the manuscript: PK. The first version of this manuscript was written as a "Saroppgave" of the medical degree program at the University of Bergen (VM), and the final version was prepared as part of employment at the University of Bergen (PK).

Funding Open access funding provided by University of Bergen (incl Haukeland University Hospital). This work received no external funding.

Data availability All data are freely available upon request.

\section{Declarations}

Conflict of interest The authors declare that there is no conflict of interest.

Research involving human and animals participants No research involving humans or animals was carried out.

Informed consent Not relevant for the current study.

Open Access This article is licensed under a Creative Commons Attribution 4.0 International License, which permits use, sharing, adaptation, distribution and reproduction in any medium or format, as long as you give appropriate credit to the original author(s) and the source, provide a link to the Creative Commons licence, and indicate if changes were made. The images or other third party material in this article are included in the article's Creative Commons licence, unless indicated otherwise in a credit line to the material. If material is not included in the article's Creative Commons licence and your intended use is not permitted by statutory regulation or exceeds the permitted use, you will need to obtain permission directly from the copyright holder. To view a copy of this licence, visit http://creativecommons.org/licenses/by/4.0/.

\section{References}

Aggarwal S, Snaidero N, Pähler G, Frey S, Sánchez P, Zweckstetter M, Janshoff A, Schneider A, Weil MT, Schaap IA, Görlich D, Simons M (2013) Myelin membrane assembly is driven by a phase transition of myelin basic proteins into a cohesive protein meshwork. PLoS Biol 11:e1001577. https://doi.org/10. 1371/journal.pbio.1001577

Ainger K, Avossa D, Morgan F, Hill SJ, Barry C, Barbarese E, Carson JH (1993) Transport and localization of exogenous myelin basic protein mRNA microinjected into oligodendrocytes. J Cell Biol 123:431-441. https://doi.org/10.1083/jcb.123.2.431

Ainger K, Avossa D, Diana AS, Barry C, Barbarese E, Carson JH (1997) Transport and localization elements in myelin basic protein mRNA. J Cell Biol 138:1077-1087. https://doi.org/10. 1083/jcb.138.5.1077

Barbarese E, Carson JH, Braun PE (1978) Accumulation of the four myelin basic proteins in mouse brain during development. J Neurochem 31:779-782. https://doi.org/10.1111/j.1471-4159. 1978.tb00110.x

Barbarese E, Koppel DE, Deutscher MP, Smith CL, Ainger K, Morgan F, Carson JH (1995) Protein translation components are colocalized in granules in oligodendrocytes. J Cell Sci 108:2781-2790

Barkhof F, Frequin ST, Hommes OR, Lamers K, Scheltens P, van Geel WJ, Valk J (1992) A correlative triad of gadolinium-DTPA MRI, EDSS, and CSF-MBP in relapsing multiple sclerosis patients treated with high-dose intravenous methylprednisolone. Neurology 42:63-67. https://doi.org/10.1212/wnl.42.1.63

Baryłko B, Dobrowolski Z (1984) Ca2+-calmodulin-dependent regulation of F-actin-myelin basic protein interaction. Eur J Cell Biol 35:327-335

Beniac DR, Wood DD, Palaniyar N, Ottensmeyer FP, Moscarello MA, Harauz G (1999) Marburg's variant of multiple sclerosis correlates with a less compact structure of myelin basic protein. Mol Cell Biol Res Commun 1:48-51. https://doi.org/10.1006/ mcbr.1999.0111

Berger T, Rubner P, Schautzer F, Egg R, Ulmer H, Mayringer I, Dilitz E, Deisenhammer F, Reindl M (2003) Antimyelin antibodies as a predictor of clinically definite multiple sclerosis after a first demyelinating event. N Engl J Med 349:139-145. https://doi. org/10.1056/NEJMoa022328

Bielekova B, Goodwin B, Richert N, Cortese I, Kondo T, Afshar G, Gran B, Eaton J, Antel J, Frank JA, McFarland HF, Martin R (2000) Encephalitogenic potential of the myelin basic protein peptide (amino acids 83-99) in multiple sclerosis: results of a phase II clinical trial with an altered peptide ligand. Nat Med 6:1167-1175. https://doi.org/10.1038/80516

Bird TD, Farrell DF, Sumi SM (1978) Brain lipid composition of the shiverer mouse: (genetic defect in myelin development). J Neurochem 31:387-391. https://doi.org/10.1111/j.1471-4159.1978. tb12479.x

Boggs JM (2006) Myelin basic protein: a multifunctional protein. Cell Mol Life Sci 63:1945-1961. https://doi.org/10.1007/ s00018-006-6094-7

Boggs JM, Rangaraj G, Koshy KM, Ackerley C, Wood DD, Moscarello MA (1999) Highly deiminated isoform of myelin basic protein 
from multiple sclerosis brain causes fragmentation of lipid vesicles. J Neurosci Res 57:529-535

Boggs JM, Rangaraj G, Heng YM, Liu Y, Harauz G (2011) Myelin basic protein binds microtubules to a membrane surface and to actin filaments in vitro: effect of phosphorylation and deimination. Biochim Biophys Acta 1808:761-773. https://doi.org/10. 1016/j.bbamem.2010.12.016

Boullerne AI (2016) The history of myelin. Exp Neurol 283:431-445. https://doi.org/10.1016/j.expneurol.2016.06.005

Brocke S, Gijbels K, Allegretta M, Ferber I, Piercy C, Blankenstein T, Martin R, Utz U, Karin N, Mitchell D, Veromaa T, Waisman A, Gaur A, Conlon P, Ling N, Fairchild PJ, Wraith DC, O'Garra A, Fathman CG, Steinman L (1996) Treatment of experimental encephalomyelitis with a peptide analogue of myelin basic protein. Nature 379:343-346. https://doi.org/10.1038/379343a0

Cao L, Goodin R, Wood D, Moscarello MA, Whitaker JN (1999) Rapid release and unusual stability of immunodominant peptide 45-89 from citrullinated myelin basic protein. Biochemistry 38:61576163. https://doi.org/10.1021/bi982960s

Carnegie PR (1971) Amino acid sequence of the encephalitogenic basic protein from human myelin. Biochem J 123:57-67. https://doi. org/10.1042/bj1230057

Carson JH, Worboys K, Ainger K, Barbarese E (1997) Translocation of myelin basic protein mRNA in oligodendrocytes requires microtubules and kinesin. Cell Motil Cytoskeleton 38:318-328. https://doi.org/10.1002/(SICI)1097-0169(1997)38:4\%3c318:: AID-CM2\%3e3.0.CO;2-\#

Chan KF, Robb ND, Chen WH (1990) Myelin basic protein: interaction with calmodulin and gangliosides. J Neurosci Res 25:535-544. https://doi.org/10.1002/jnr.490250410

Chao LP, Einstein ER (1970) Physical properties of the bovine encephalitogenic protein; molecular weight and conformation. $\mathbf{J}$ Neurochem 17:1121-1132. https://doi.org/10.1111/j.1471-4159. 1970.tb03360.x

Cilia E, Pancsa R, Tompa P, Lenaerts T, Vranken WF (2014) The DynaMine webserver: predicting protein dynamics from sequence. Nucleic Acids Res 42:W264-W270. https://doi.org/ 10.1093/nar/gku270

Colman DR, Kreibich G, Frey AB, Sabatini DD (1982) Synthesis and incorporation of myelin polypeptides into CNS myelin. J Cell Biol 95:598-608. https://doi.org/10.1083/jcb.95.2.598

Constantinescu CS, Farooqi N, O’Brien K, Gran B (2011) Experimental autoimmune encephalomyelitis (EAE) as a model for multiple sclerosis (MS). Br J Pharmacol 164:1079-1106. https://doi.org/ 10.1111/j.1476-5381.2011.01302.x

Cusick MF, Libbey JE, Fujinami RS (2012) Molecular mimicry as a mechanism of autoimmune disease. Clin Rev Allergy Immunol 42:102-111. https://doi.org/10.1007/s12016-011-8294-7

Dupouey P, Jacque C, Bourre JM, Cesselin F, Privat A, Baumann N (1979) Immunochemical studies of myelin basic protein in shiverer mouse devoid of major dense line of myelin. Neurosci Lett 12:113-118. https://doi.org/10.1016/0304-3940(79)91490-3

Einstein ER, Robertson DM, DiCaprio JM, Moore W (1962) The isolation from bovine spinal cord of a homogeneous protein with encephalitogenic activity. J Neurochem 9:353-361. https://doi. org/10.1111/j.1471-4159.1962.tb09461.x

Esmaeilizade Z, Mohammadi B, Omrani MD, Ghaderian SMH, Rajabibazl M, Fazeli Z (2021) Preclinical studies and clinical trials with mesenchymal stem cell for demyelinating diseases: a systematic review. Curr Stem Cell Res Ther. https://doi.org/10.2174/ 1574888X16666210208162318

Eylar EH (1970) Amino acid sequence of the basic protein of the myelin membrane. Proc Natl Acad Sci USA 67:1425-1431. https:// doi.org/10.1073/pnas.67.3.1425
Eylar EH, Brostoff S, Hashim G, Caccam J, Burnett P (1971) Basic A1 protein of the myelin membrane. The complete amino acid sequence. J Biol Chem 246:5770-5784

Fornasiero EF, Mandad S, Wildhagen H, Alevra M, Rammner B, Keihani S, Opazo F, Urban I, Ischebeck T, Sakib MS, Fard MK, Kirli K, Centeno TP, Vidal RO, Rahman RU, Benito E, Fischer A, Dennerlein S, Rehling P, Feussner I, Bonn S, Simons M, Urlaub H, Rizzoli SO (2018) Precisely measured protein lifetimes in the mouse brain reveal differences across tissues and subcellular fractions. Nat Commun 9:4230. https://doi.org/10.1038/ s41467-018-06519-0

Franklin RJM, Frisén J, Lyons DA (2020) Revisiting remyelination: towards a consensus on the regeneration of CNS myelin. Semin Cell Dev Biol. https://doi.org/10.1016/j.semcdb.2020.09.009

Fujinami RS, Oldstone MB (1985) Amino acid homology between the encephalitogenic site of myelin basic protein and virus: mechanism for autoimmunity. Science 230:1043-1045. https://doi.org/ 10.1126/science. 2414848

Füst G (2011) The role of the Epstein-Barr virus in the pathogenesis of some autoimmune disorders-similarities and differences. Eur J Microbiol Immunol (bp) 1:267-278. https://doi.org/10.1556/ EuJMI.1.2011.4.2

Gabibov AG, Belogurov AA, Lomakin YA, Zakharova MY, Avakyan ME, Dubrovskaya VV, Smirnov IV, Ivanov AS, Molnar AA, Gurtsevitch VE, Diduk SV, Smirnova KV, Avalle B, Sharanova SN, Tramontano A, Friboulet A, Boyko AN, Ponomarenko NA, Tikunova NV (2011) Combinatorial antibody library from multiple sclerosis patients reveals antibodies that cross-react with myelin basic protein and EBV antigen. FASEB J 25:4211-4221. https://doi.org/10.1096/fj.11-190769

Gasperoni F, Turini P, Agostinelli E (2019) A novel comprehensive paradigm for the etiopathogenesis of multiple sclerosis: therapeutic approaches and future perspectives on its treatment. Amino Acids 51:745-759. https://doi.org/10.1007/s00726-019-02718-1

Genc B, Bozan HR, Genc S, Genc K (2019) Stem cell therapy for multiple sclerosis. Adv Exp Med Biol 1084:145-174. https:// doi.org/10.1007/5584_2018_247

Ghasemi N, Razavi S, Nikzad E (2017) Multiple sclerosis: pathogenesis, symptoms, diagnoses and cell-based therapy. Cell J 19:1-10. https://doi.org/10.22074/cellj.2016.4867

Givogri MI, Bongarzone ER, Schonmann V, Campagnoni AT (2001) Expression and regulation of golli products of myelin basic protein gene during in vitro development of oligodendrocytes. J Neurosci Res 66:679-690. https://doi.org/10.1002/jnr.10031

Gobbin F, Zanoni M, Marangi A, Orlandi R, Crestani L, Benedetti MD, Gajofatto A (2019) 2017 McDonald criteria for multiple sclerosis: earlier diagnosis with reduced specificity. Mult Scler Relat Disord 29:23-25. https://doi.org/10.1016/j.msard.2019.01.008

Gogate N, Verma L, Zhou JM, Milward E, Rusten R, O'Connor M, Kufta C, Kim J, Hudson L, Dubois-Dalcq M (1994) Plasticity in the adult human oligodendrocyte lineage. J Neurosci 14:4571-4587

Gouet P, Courcelle E, Stuart DI, Métoz F (1999) ESPript: analysis of multiple sequence alignments in PostScript. Bioinformatics 15:305-308. https://doi.org/10.1093/bioinformatics/15.4.305

Greene DN, Schmidt RL, Wilson AR, Freedman MS, Grenache DG (2012) Cerebrospinal fluid myelin basic protein is frequently ordered but has little value: a test utilization study. Am J Clin Pathol 138:262-272. https://doi.org/10.1309/AJCPCYCH96 QYPHJM

Grima B, Zelenika D, Pessac B (1992) A novel transcript overlapping the myelin basic protein gene. J Neurochem 59:2318-2323. https://doi.org/10.1111/j.1471-4159.1992.tb10126.x

Guan Y, Jakimovski D, Ramanathan M, Weinstock-Guttman B, Zivadinov R (2019) The role of Epstein-Barr virus in multiple 
sclerosis: from molecular pathophysiology to in vivo imaging. Neural Regen Res 14:373-386. https://doi.org/10.4103/16735374.245462

Harauz G, Libich DS (2009) The classic basic protein of myelin-conserved structural motifs and the dynamic molecular barcode involved in membrane adhesion and protein-protein interactions. Curr Protein Pept Sci 10:196-215. https://doi.org/10.2174/13892 0309788452218

Harauz G, Ladizhansky V, Boggs JM (2009) Structural polymorphism and multifunctionality of myelin basic protein. Biochemistry 48:8094-8104. https://doi.org/10.1021/bi901005f

Jacque C, Delassalle A, Rancurel G, Raoul M, Lesourd B, Legrand JC (1982) Myelin basic protein in CSF and blood. Relationship between its presence and the occurrence of a destructive process in the brains of encephalitic patients. Arch Neurol 39:557-560. https://doi.org/10.1001/archneur.1982.00510210027006

Jalilian B, Einarsson HB, Vorup-Jensen T (2012) Glatiramer acetate in treatment of multiple sclerosis: a toolbox of random co-polymers for targeting inflammatory mechanisms of both the innate and adaptive immune system. Int J Mol Sci 13:14579-14605. https://doi.org/10.3390/ijms131114579

Jog NR, McClain MT, Heinlen LD, Gross T, Towner R, Guthridge JM, Axtell RC, Pardo G, Harley JB, James JA (2020) Epstein Barr virus nuclear antigen 1 (EBNA-1) peptides recognized by adult multiple sclerosis patient sera induce neurologic symptoms in a murine model. J Autoimmun 106:102332. https://doi. org/10.1016/j.jaut.2019.102332

Katsavos S, Anagnostouli M (2013) Biomarkers in multiple sclerosis: an up-to-date overview. Mult Scler Int 2013:340508. https://doi.org/10.1155/2013/340508

Kim JK, Mastronardi FG, Wood DD, Lubman DM, Zand R, Moscarello MA (2003) Multiple sclerosis: an important role for post-translational modifications of myelin basic protein in pathogenesis. Mol Cell Proteomics 2:453-462. https://doi.org/ 10.1074/mcp.M200050-MCP200

Kim HJ, Tsao JW, Stanfill AG (2018) The current state of biomarkers of mild traumatic brain injury. JCI Insight. https://doi.org/10. 1172/jci.insight.97105

Koshihara H, Oguchi K, Takei Y, Kitazawa K, Higuchi K, Ohara S (2014) Meningeal inflammation and demyelination in a patient clinically diagnosed with acute disseminated encephalomyelitis. J Neurol Sci 346:323-327. https://doi.org/10.1016/j.jns. 2014.08.037

Krigbaum WR, Hsu TS (1975) Molecular conformation of bovine A1 basic protein, a coiling macromolecule in aqueous solution. Biochemistry 14:2542-2546. https://doi.org/10.1021/ bi00682a038

Kuhle J, Lindberg RL, Regeniter A, Mehling M, Hoffmann F, Reindl M, Berger T, Radue EW, Leppert D, Kappos L (2007a) Antimyelin antibodies in clinically isolated syndromes correlate with inflammation in MRI and CSF. J Neurol 254:160-168. https:// doi.org/10.1007/s00415-006-0299-4

Kuhle J, Pohl C, Mehling M, Edan G, Freedman MS, Hartung HP, Polman CH, Miller DH, Montalban X, Barkhof F, Bauer L, Dahms S, Lindberg R, Kappos L, Sandbrink R (2007b) Lack of association between antimyelin antibodies and progression to multiple sclerosis. N Engl J Med 356:371-378. https://doi.org/10.1056/ NEJMoa063602

Lamers KJ, de Reus HP, Jongen PJ (1998) Myelin basic protein in CSF as indicator of disease activity in multiple sclerosis. Mult Scler 4:124-126. https://doi.org/10.1177/135245859800400306

Libich DS, Harauz G (2002) Interactions of the 18.5-kDa isoform of myelin basic protein with $\mathrm{Ca}(2+)$-calmodulin: in vitro studies using fluorescence microscopy and spectroscopy. Biochem Cell Biol 80:395-406. https://doi.org/10.1139/o02-020
Majava V, Petoukhov MV, Hayashi N, Pirilä P, Svergun DI, Kursula $P$ (2008) Interaction between the C-terminal region of human myelin basic protein and calmodulin: analysis of complex formation and solution structure. BMC Struct Biol 8:10. https://doi. org/10.1186/1472-6807-8-10

Majava V, Wang C, Myllykoski M, Kangas SM, Kang SU, Hayashi N, Baumgärtel P, Heape AM, Lubec G, Kursula P (2010) Structural analysis of the complex between calmodulin and full-length myelin basic protein, an intrinsically disordered molecule. Amino Acids 39:59-71. https://doi.org/10.1007/s00726-009-0364-2

Mastronardi FG, Moscarello MA (2005) Molecules affecting myelin stability: a novel hypothesis regarding the pathogenesis of multiple sclerosis. J Neurosci Res 80:301-308. https://doi.org/10. 1002/jnr.20420

McGinley MP, Goldschmidt CH, Rae-Grant AD (2021) Diagnosis and treatment of multiple sclerosis: a review. JAMA 325:765-779. https://doi.org/10.1001/jama.2020.26858

Miller DH, Chard DT, Ciccarelli O (2012) Clinically isolated syndromes. Lancet Neurol 11:157-169. https://doi.org/10.1016/ S1474-4422(11)70274-5

Muruganandam G, Bürck J, Ulrich AS, Kursula I, Kursula P (2013) Lipid membrane association of myelin proteins and peptide segments studied by oriented and synchrotron radiation circular dichroism spectroscopy. J Phys Chem B 117:14983-14993. https://doi.org/10.1021/jp4098588

Neumann B, Segel M, Chalut KJ, Franklin RJ (2019) Remyelination and ageing: reversing the ravages of time. Mult Scler 25:18351841. https://doi.org/10.1177/1352458519884006

Nguyen H, James EA (2016) Immune recognition of citrullinated epitopes. Immunology 149:131-138. https://doi.org/10.1111/ imm. 12640

Nonneman A, Robberecht W, Den Bosch LV (2014) The role of oligodendroglial dysfunction in amyotrophic lateral sclerosis. Neurodegener Dis Manag 4:223-239

Obradovic Z, Peng K, Vucetic S, Radivojac P, Brown CJ, Dunker AK (2003) Predicting intrinsic disorder from amino acid sequence. Proteins 53(Suppl 6):566-572. https://doi.org/10.1002/prot. 10532

Ohta M, Nishitani H, Matsubara F, Inaba G (1980) Myelin basic protein in spinal fluid from patients with neuro-Behcet's disease. N Engl J Med 302:1093. https://doi.org/10.1056/NEJM1 98005083021922

Ohta M, Ohta K, Nishimura M, Saida T (2002) Detection of myelin basic protein in cerebrospinal fluid and serum from patients with HTLV-1-associated myelopathy/tropical spastic paraparesis. Ann Clin Biochem 39:603-605. https://doi.org/10.1177/ 000456320203900610

Pelayo R, Tintoré M, Montalban X, Rovira A, Espejo C, Reindl M, Berger T (2007) Antimyelin antibodies with no progression to multiple sclerosis. N Engl J Med 356:426-428. https://doi.org/ 10.1056/NEJMc062467

Planas R, Santos R, Tomas-Ojer P, Cruciani C, Lutterotti A, Faigle W, Schaeren-Wiemers N, Espejo C, Eixarch H, Pinilla C, Martin R, Sospedra M (2018) GDP-1-fucose synthase is a CD4 ${ }^{+} \mathrm{T}$ cell-specific autoantigen in DRB3 $\times 02: 02$ patients with multiple sclerosis. Sci Transl Med 10:eaat4301. https://doi.org/10. 1126/scitranslmed.aat4301

Polverini E, Rangaraj G, Libich DS, Boggs JM, Harauz G (2008) Binding of the proline-rich segment of myelin basic protein to SH3 domains: spectroscopic, microarray, and modeling studies of ligand conformation and effects of posttranslational modifications. Biochemistry 47:267-282. https://doi.org/10. 1021/bi701336n

Poser CM, Paty DW, Scheinberg L, McDonald WI, Davis FA, Ebers GC, Johnson KP, Sibley WA, Silberberg DH, Tourtellotte WW (1983) New diagnostic criteria for multiple sclerosis: 
guidelines for research protocols. Ann Neurol 13:227-231. https://doi.org/10.1002/ana.410130302

Privat A, Jacque C, Bourre JM, Dupouey P, Baumann N (1979) Absence of the major dense line in myelin of the mutant mouse "shiverer." Neurosci Lett 12:107-112. https://doi.org/10.1016/ 0304-3940(79)91489-7

Raasakka A, Ruskamo S, Kowal J, Barker R, Baumann A, Martel A, Tuusa J, Myllykoski M, Bürck J, Ulrich AS, Stahlberg H, Kursula P (2017) Membrane association landscape of myelin basic protein portrays formation of the myelin major dense line. Sci Rep 7:4974. https://doi.org/10.1038/s41598-017-05364-3

Re A, Giachetti R (1999) Acute disseminated encephalomyelitis (ADEM) after autologous peripheral blood stem cell transplant for non-Hodgkin's lymphoma. Bone Marrow Transplant 24:1351-1354. https://doi.org/10.1038/sj.bmt.1702047

Readhead C, Hood L (1990) The dysmyelinating mouse mutations shiverer (shi) and myelin deficient (shimld). Behav Genet 20:213-234. https://doi.org/10.1007/BF01067791

Roth GA, Gonzalez MD, Monferran CG, De Santis ML, Cumar FA (1993) Myelin basic protein domains involved in the interaction with actin. Neurochem Int 23:459-465. https://doi.org/10.1016/ 0197-0186(93)90130-w

Sellebjerg F, Christiansen M, Garred P (1998) MBP, anti-MBP and anti-PLP antibodies, and intrathecal complement activation in multiple sclerosis. Mult Scler 4:127-131. https://doi.org/10. $1177 / 135245859800400307$

Smith GS, Homchaudhuri L, Boggs JM, Harauz G (2012) Classic 18.5- and $21.5-\mathrm{kDa}$ myelin basic protein isoforms associate with cytoskeletal and SH3-domain proteins in the immortalized N19-oligodendroglial cell line stimulated by phorbol ester and IGF-1. Neurochem Res 37:1277-1295. https://doi.org/10.1007/ s11064-011-0700-2

Snaidero N, Möbius W, Czopka T, Hekking LH, Mathisen C, Verkleij D, Goebbels S, Edgar J, Merkler D, Lyons DA, Nave KA, Simons M (2014) Myelin membrane wrapping of CNS axons by $\mathrm{PI}(3,4,5) \mathrm{P} 3$-dependent polarized growth at the inner tongue. Cell 156:277-290. https://doi.org/10.1016/j.cell.2013.11.044

Snaidero N, Velte C, Myllykoski M, Raasakka A, Ignatev A, Werner HB, Erwig MS, Möbius W, Kursula P, Nave KA, Simons M (2017) Antagonistic functions of MBP and CNP establish cytosolic channels in CNS myelin. Cell Rep 18:314-323. https://doi. org/10.1016/j.celrep.2016.12.053

Stapulionis R, Oliveira CL, Gjelstrup MC, Pedersen JS, Hokland ME, Hoffmann SV, Poulsen K, Jacobsen C, Vorup-Jensen T (2008) Structural insight into the function of myelin basic protein as a ligand for integrin alpha M beta 2. J Immunol 180:3946-3956. https://doi.org/10.4049/jimmunol.180.6.3946

Stavrou M, Sargiannidou I, Christofi T, Kleopa KA (2021) Genetic mechanisms of peripheral nerve disease. Neurosci Lett 742:135357. https://doi.org/10.1016/j.neulet.2020.135357

Strand T, Alling C, Karlsson B, Karlsson I, Winblad B (1984) Brain and plasma proteins in spinal fluid as markers for brain damage and severity of stroke. Stroke 15:138-144. https://doi.org/10. 1161/01.str.15.1.138

Stromnes IM, Goverman JM (2006a) Active induction of experimental allergic encephalomyelitis. Nat Protoc 1:1810-1819. https://doi. org/10.1038/nprot.2006.285

Stromnes IM, Goverman JM (2006b) Passive induction of experimental allergic encephalomyelitis. Nat Protoc 1:1952-1960. https://doi. org/10.1038/nprot.2006.284

Teitelbaum D, Meshorer A, Hirshfeld T, Arnon R, Sela M (1971) Suppression of experimental allergic encephalomyelitis by a synthetic polypeptide. Eur J Immunol 1:242-248. https://doi.org/ 10.1002/eji.1830010406

Tompa P, Szász C, Buday L (2005) Structural disorder throws new light on moonlighting. Trends Biochem Sci 30:484-489. https://doi. org/10.1016/j.tibs.2005.07.008
Toyama BH, Savas JN, Park SK, Harris MS, Ingolia NT, Yates JR, Hetzer MW (2013) Identification of long-lived proteins reveals exceptional stability of essential cellular structures. Cell 154:971-982. https://doi.org/10.1016/j.cell.2013.07.037

Van Haren K, Tomooka BH, Kidd BA, Banwell B, Bar-Or A, Chitnis T, Tenembaum SN, Pohl D, Rostasy K, Dale RC, O’Connor KC, Hafler DA, Steinman L, Robinson WH (2013) Serum autoantibodies to myelin peptides distinguish acute disseminated encephalomyelitis from relapsing-remitting multiple sclerosis. Mult Scler 19:1726-1733. https://doi.org/10.1177/1352458513485653

Van Leeuwenhoek A (1719) Epistolae physiologicae super compluribus naturae arcanis, Apud Adrianum Beman,

Vassall KA, Bamm VV, Harauz G (2015) MyelStones: the executive roles of myelin basic protein in myelin assembly and destabilization in multiple sclerosis. Biochem J 472:17-32. https://doi.org/ 10.1042/BJ20150710

Villar LM, Espiño M, Roldán E, Marín N, Costa-Frossard L, Muriel A, Alvarez-Cermeño JC (2011) Increased peripheral blood CD5+ $\mathrm{B}$ cells predict earlier conversion to MS in high-risk clinically isolated syndromes. Mult Scler 17:690-694. https://doi.org/10. $1177 / 1352458510396922$

Virchow R (1854) Ueber das ausgebreitete Vorkommen einer dem Nervenmark analogen Substanz in den thierischen Geweben. Archiv Für Pathologische Anatomie Und Physiologie Und Für Klinische Medicin 6:562-572

Voskuhl RR, McFarlin DE, Stone R, McFarland HF (1993) T-lymphocyte recognition of a portion of myelin basic protein encoded by an exon expressed during myelination. J Neuroimmunol 42:187191. https://doi.org/10.1016/0165-5728(93)90009-n

Wang C, Neugebauer U, Bürck J, Myllykoski M, Baumgärtel P, Popp J, Kursula P (2011) Charge isomers of myelin basic protein: structure and interactions with membranes, nucleotide analogues, and calmodulin. PLoS ONE 6:e19915. https://doi.org/10.1371/journ al.pone.0019915

Wang J, Ho WY, Lim K, Feng J, Tucker-Kellogg G, Nave KA, Ling SC (2018) Cell-autonomous requirement of TDP-43, an ALS/FTD signature protein, for oligodendrocyte survival and myelination. Proc Natl Acad Sci USA 115:E10941-E10950. https://doi.org/ 10.1073/pnas. 1809821115

Wood DD, Moscarello MA (1989) The isolation, characterization, and lipid-aggregating properties of a citrulline containing myelin basic protein. J Biol Chem 264:5121-5127

Wood DD, Bilbao JM, O’Connors P, Moscarello MA (1996) Acute multiple sclerosis (Marburg type) is associated with developmentally immature myelin basic protein. Ann Neurol 40:18-24. https://doi.org/10.1002/ana.410400106

Xue B, Dunbrack RL, Williams RW, Dunker AK, Uversky VN (2010) PONDR-FIT: a meta-predictor of intrinsically disordered amino acids. Biochim Biophys Acta 1804:996-1010. https://doi.org/10. 1016/j.bbapap.2010.01.011

Zavialova MG, Shevchenko VE, Nikolaev EN, Zgoda VG (2017) Is myelin basic protein a potential biomarker of brain cancer. Eur J Mass Spectrom (chichester) 23:192-196. https://doi.org/10.1177/ 1469066717719810

Zhou T, Ahmad TK, Gozda K, Truong J, Kong J, Namaka M (2017) Implications of white matter damage in amyotrophic lateral sclerosis (review). Mol Med Rep 16:4379-4392. https://doi.org/10. 3892/mmr.2017.7186

Publisher's Note Springer Nature remains neutral with regard to jurisdictional claims in published maps and institutional affiliations. 